\title{
Quality, Yield, and Survival of Asiatic Blue- stems and an Eastern Gamagrass in Southern Illinois
}

\author{
J.J. FAIX, C.J. KAISER, AND F.C. HINDS
}

\section{Abstract}

Six Asiatic bluestems (Bothriochloa spp.) B. caucasica, cv. Caucasian, $B$. ischaemum var. ischaemum cv. Plains, and 4 experimental strains of $B$. Intermedia $\times B$. ischaemum $(B, L, L L$, and $T)$, and an Eastern gamagrass (Tripsacum dactyloides cv. PM-K-24) were grown in southern Illinois on a Typic Fragiudalf soil common to the Central U.S. Transitional Zone. The grasses were evaluated from 1975 through 1977 for yield, crude protein (CP), and in vitro digestibility (IVD) to determine their potential as alternatives to "summer dormant" tall fescue (Festuca arundinaceae) in southern Illinois. Average seasonal dry matter yields ranged from 10 to 15 metric tons per hectare. Eastern gamagrass was slower to establish than the bluestems, but after the first production year it was higher yielding than the bluestems. Forage $\mathrm{CP}$ and IVD averaged near 11 and $50 \%$, respectively, over the 3 -year period. There was little difference between the grasses for $\mathrm{CP}$, but IVD of Caucasian bluestem was significantly lower than that of the other bluestems and Eastern gamagrass. All the grasses survived the three winters that yield and quality data were taken, but in two subsequent severe winters only Caucasian bluestem and the Eastern gamagrass were winter hardy.

The transition zone extends from south central Missouri across southern Illinois and eastward. This zone is subject to highly variable inter and intraseasonal temperature and rainfall patterns, the result of frequent but irregular advance and retreat of Canadian and Gulf of Mexico frontal air masses. The shallow unglaciated loess soils throughout much of the zone are underlain by silaceous silt pans (Steinhardt and Franzmeier 1979) that result in "perched" water tables and saturated soils in the winter and imminent drought after only short periods without rainfall in the summer. Tall fescue (Festuca arundinacea) is well adapted in this zone and is productive and of satisfactory forage quality in spring and fall, but high temperatures reduce both growth and forage quality of fescue in the summer (Kaiser et al. 1974; Mott et al. 1971). Increased alkaloid concentration (Bush et al. 1972) and decreased soluble carbohydrate levels (Smith 1977; Vartha et al. 1977) appear to explain the low quality of fescue in the summer.

It is possible that certain warm-season grasses may potentially be used to supplement tall fescue in the summer in southern Illinois and the transition zone. The Asiatic bluestems Bothriochloa spp. (Harlan et al. 1962; Roundtree et al.

\footnotetext{
Authors are assistant professor of agronomy, University of Illinois Dixon Springs Agricultural Center, Simpson, Illinois 62985; associate professor of agronomy, University of Illinois Dixon Springs Agricultural Center, Simpson, Illinois 62985; and professor of animal science, Department of Animal Science, University of Illinois, Urbana, Illinois 61801

Appreciation is expressed to C.M. Taliaferro of Oklahoma State University, to the Kansas SCS-PMC, Manhattan, and R.R. Brown, PMC-SCS, Columbia, Missouri, for furnishing plant materials used in this study.

Manuscript received May 6, 1979.
}

1974; Taliaferro and Harland 1973) may offer more vigorous summer forage than the difficult to manage native range or prairie grasses (Branson 1953). In Missouri (Roundtree et al. 1974) Caucasian bluestem (B. caucasica) outyielded Midland bermudagrass (Cynodon dactylon) in clipping trials, and in grazing trials Caucasian bluestem gave higher average daily gains than switchgrass (Panicum virgatum). Plains bluestem (B. ischaemum var. ischaemum), released in 1973, was reported to be higher in in vitro digestibility than Caucasian bluestem (Taliaferro and Harlan 1973). Although Eastern ga magrass is regarded to be high yielding and highly palatable (Schwendiman and Hawk 1973), there is little or no research documentation. Fraps and Fudge (1945) ran proximate analyses on 64 pasture and range grasses, and in their data nitrogen free extract of Eastern gamagrass appeared to be somewhat higher than in the other grasses.

The objective of this study was to evaluate various selections and experimental strains of Asiatic bluestems and an Eastern gamagrass for crude protein $(\mathrm{CP})$, in vitro digestibility (IVD), yield, and winter survival. The ultimate purpose was to determine which of the grasses would offer the best alternative to tall fescue for the summer in southern Illinois or the transitional zone.

\section{Methods}

Asiatic bluestems included in this study were Caucasian, Plains, and experimental strains $\mathrm{B}, \mathrm{L}, \mathrm{LL}$, and T. The Eastern gamagrass (PM-K-24) was from a seed increase of a bulked planting of 70 Kansas and Oklahoma collections made in 1958 (Hanson 1972). The bluestems and gamagrass were planted June 20,1974, at approximately 5 and $11 \mathrm{~kg} /$ ha, respectively, in paired $76 \mathrm{~cm}$-wide rows $3 \mathrm{~m}$ long. There were two replications arranged in a randomized complete block design. The soil was a Typic Fragiudalf (family fine-silty, mixed, mesic, series (Grantsburg) with a $\mathrm{pH}$ of 6.8 , and phosphorus (P) and potassium (K) levels of 12 and $200 \mathrm{~kg} / \mathrm{ha}$, respectively. Two hundred and twenty-four $\mathrm{kg} / \mathrm{ha}$ of $12-19.9-10.5$ fertilizer was broadcast and incorporated prior to planting. Nitrogen was topdressed at $150 \mathrm{~kg} /$ ha in July of each year.

In $1975, .09 \times 1.8 \mathrm{~m}$ areas were harvested between the rows with a self-propelled flair harvester. In 1976 and 1977, harvests were made of $0.1 \mathrm{~m}^{2}$ sections in each row. Clipping height was $15 \mathrm{~cm}$ in 1975 and 3-4 cm in 1976 and 1977 . Harvests were planned for when the plants reached the late boot stage of growth. Three harvests were made in 1975 and 1977 and 4 in 1976. No yields were taken in 1978 , but the plots were clipped twice. Following each harvest, samples were dried at $60^{\circ} \mathrm{C}$ in a forced draft oven and were subsequently ground in a Wiley Mill to pass a 20-mesh screen. Nitrogen content was determined by a standard Kjeldahl procedure, and crude protein was estimated by multiplying the $\mathrm{N}$ percen- 
tage by 6.25 . In vitro digestibility analyses were made with the Barnes (1969) modification of the Tilly and Terry procedure. Rumen fluid was obtained from a fistulated sheep fed a mixed grass-legume hay and mineral supplement.

Dry matter yields, crude protein, and in vitro digestibility data were statistically analyzed with grass entries as main plots and harvest dates or years as subplots. The range of percentages for CP and IVD was narrow enough so that angular transformation of the data was not necessary.

\section{Results}

\section{Forage Quality}

Average annual $\mathrm{CP}$ of the grasses ranged from 10 to $11.2 \%$ (Table 1). Lowest $\mathrm{CP}$ for individual harvests was recorded for Caucasian bluestem but the average $\mathrm{CP}$ content of Caucasian was not significantly different $(P<.05)$ from that of the other grasses (Table 1). Lower average CP in 1975 than in the other years (Table 1) was primarily due to

Table 1. Average crude protein (\%) of Asiatic bluestems and an Eastern gamagrass 1975, 1976, 1977.

\begin{tabular}{lrrrrr}
\hline & \multicolumn{3}{c}{ Year } \\
\cline { 2 - 4 } Cultivar & 1975 & 1976 & 1977 & Average \\
\hline Caucasian bluestem & 9.5 & 10.7 & 10.0 & $10.1 \mathrm{a}^{\mathrm{l}}$ \\
Oklahoma B bluestem & 10.1 & 11.4 & 11.4 & $11.0 \mathrm{a}$ \\
Oklahoma L bluestem & 10.1 & 11.8 & 11.3 & $11.0 \mathrm{a}$ \\
Oklahoma LL bluestem & 9.7 & 11.1 & 10.8 & $10.5 \mathrm{a}$ \\
Oklahoma T bluestem & 10.5 & 11.5 & 11.2 & $11.0 \mathrm{a}$ \\
Plains bluestem & 9.6 & 11.2 & 10.8 & $10.5 \mathrm{a}$ \\
Eastern gamagrass PM-K-24 & 10.7 & 10.6 & 11.0 & $10.7 \mathrm{a}$ \\
& Average & $10.0 \mathrm{~b}$ & $11.2 \mathrm{a}$ & $10.9 \mathrm{a}$ & \\
\hline
\end{tabular}

IValues without letters in common are significantly different (Duncan's multiple range tcst, $P<.05$ ).

a warm spring and summer that caused rapid plant maturation between harvests. In contrast a cool 1976 summer (average temperature minimum for May through August was $9.6^{\circ} \mathrm{C}$ vs. $13.5^{\circ} \mathrm{C}$ in 1975 ) resulted in slower growth and higher $\mathrm{CP}$ levels, but the average was decreased by low CP in advanced growth harvested in September of that year. As would be expected $\mathrm{CP}$ was highest in harvests following $\mathrm{N}$ application, but the average difference between lowest and highest harvest $\mathrm{CP}$ levels was only 2.5 percentage units. Because of its early growth and development in the spring, Eastern gamagrass was generally lower in CP than the bluestems in the first harvests, but in subsequent harvests the crude protein levels were similar. Rate of morphological development of the bluestem lines varied. Experimental strains $L$ and LL flowered before the other bluestems, especially in the first harvests, but stage of growth did not greatly affect CP or IVD level.

Table 2. In vitro digestibility (\%) of Asiatic bluestems and an Eastern gamagrass in 1975, 1976, 1977.

\begin{tabular}{lllll}
\hline \hline & \multicolumn{3}{c}{ Year } \\
\cline { 2 - 4 } Cultivar & 1975 & 1976 & 1977 & Average \\
\hline Caucasian bluestem & $46.3 \mathrm{a}^{1}$ & $49.3 \mathrm{~b}$ & $43.2 \mathrm{~d}$ & $46.3 \mathrm{~b}$ \\
Oklahoma B bluestem & $46.6 \mathrm{a}$ & $56.2 \mathrm{a}$ & $50.7 \mathrm{a}$ & $51.2 \mathrm{a}$ \\
Oklahoma L bluestem & $48.7 \mathrm{a}$ & $55.8 \mathrm{a}$ & $50.3 \mathrm{ab}$ & $51.6 \mathrm{a}$ \\
Oklahoma LL bluestem & $51.0 \mathrm{a}$ & $56.4 \mathrm{a}$ & $48.5 \mathrm{bc}$ & $52.0 \mathrm{a}$ \\
Oklahoma T bluestem & $47.9 \mathrm{a}$ & $56.0 \mathrm{a}$ & $48.9 \mathrm{a}-\mathrm{c}$ & $50.9 \mathrm{a}$ \\
Plains bluestem & $48.2 \mathrm{a}$ & $55.2 \mathrm{a}$ & $50.0 \mathrm{ab}$ & $51.1 \mathrm{a}$ \\
Eastern gamagrass PM-K-24 & $46.6 \mathrm{a}$ & $\frac{55.5 \mathrm{a}}{47.9 \mathrm{c}}$ & \\
Average & $47.9 \mathrm{~b}^{1}$ & $\frac{54.9 \mathrm{a}}{48.5 \mathrm{~b}}$ & \\
\hline
\end{tabular}

'Values without letters in common are significantly different (Duncan's multiple range test, $P<.05)$.
Average annual IVD ranged from 47.9 to $54.9 \%$ (Table 2). Higher IVD in 1976 (Table 2) as with the higher CP in 1976 (Table 1) was due to a cool summer as was described. Averaged across years Caucasian bluestem was lower in IVD than the other bluestems and Eastern gamagrass (Table 2). Caucasian has been reported to be lower in IVD than Plains bluestem (Taliaferro and Harlan 1973). Eastern gamagrass was similar in IVD to the better bluestems except in 1977 (Table 2). But, even in that year it was higher in IVD than Caucasian bluestem (Table 2). Unlike the bluestems, in the late September 1976 harvest, gamagrass CP and IVD dropped little. Late summer growth of PM-K-24 gamagrass, unlike the bluestems, remained leafy with little culm extension.

\section{Yield and Winter Survival}

Good stands of all grasses were obtained following the June 20,1974, planting. The bluestems, especially experimental LL, displayed more seedling vigor than the Eastern gamagrass. Lower average yield in 1975 than in 1976 and 1977 (Table 3) is attributed mainly to the higher stubble height left in 1975. Eastern gamagrass outyielded the bluestems except in 1975 (Table 3). In 1976 a cold spring delayed

Table 3. Three-year yield (metric ton/ha) summary of Asiatic bluestems and an Eastern gamagrass on a fragipan soil in southern Illinois.

\begin{tabular}{|c|c|c|c|c|}
\hline \multirow[b]{2}{*}{ Cultivar } & \multicolumn{3}{|c|}{ Year } & \multirow[b]{2}{*}{ Average } \\
\hline & 1975 & 1976 & 1977 & \\
\hline Caucasian bluestem & $9.50 \mathrm{a}^{1}$ & $11.47 \mathrm{~b}$ & $\mathrm{c} 15.21 \mathrm{~b}$ & $12.06 \mathrm{~b}$ \\
\hline Oklahoma B bluestem & $10.51 \mathrm{a}$ & $10.61 \mathrm{~b}$ & $\mathrm{c} 15.09 \mathrm{~b}$ & $12.07 \mathrm{~b}$ \\
\hline Oklahoma L bluestem & $12.17 \mathrm{a}$ & $11.31 \mathrm{~b}$ & $\mathrm{c} 16.20 \mathrm{~b}$ & $13.23 \mathrm{~b}$ \\
\hline Oklahoma LL bluestem & $11.36 \mathrm{a}$ & 8.25 & $15.45 \mathrm{~b}$ & $11.69 \mathrm{~b}$ \\
\hline Oklahoma T bluestem & $9.50 \mathrm{a}$ & $12.02 \mathrm{~b}$ & $\mathrm{c} 13.43 \mathrm{~b}$ & $11.65 \mathrm{~b}$ \\
\hline Plains bluestem & $11.07 \mathrm{a}$ & $14.98 \mathrm{~b}$ & $12.78 \mathrm{~b}$ & $12.94 \mathrm{~b}$ \\
\hline Eastern gamagrass PM-K-24 & $7.49 \mathrm{~b}$ & $24.33 \mathrm{a}$ & $21.20 \mathrm{a}$ & $17.67 \mathrm{a}$ \\
\hline Average & $\overline{10.23 \mathrm{~b}^{1}}$ & $13.28 \mathrm{a}$ & $\overline{15.62 \mathrm{a}}$ & \\
\hline
\end{tabular}

'Values without letters in common are significantly different (Duncan's multiple range test, $P<.05$ ).

growth of the bluestems, especially strains L, LL, and T. As a result bluestem yields averaged less than one-half that of the gamagrass in the first cutting in 1976. Generally PM-K24 gamagrass made its most vigorous growth and highest yields in the first and second harvests, but growth declined toward the end of August. Yields of 20 metric ton/ha have been obtained for Eastern gamagrass under irrigation in Oklahoma (Kessler 1978).

All the bluestems and the Eastern gamagrass in this study showed satisfactory winter hardiness from 1974 to 1977 . But following abnormally cold winters in 1978 and 1979, where soil at $5 \mathrm{~cm}$ under sod remained frozen for extended periods of time, only Caucasian bluestem and PM-K-24 Eastern gamagrass recovered each spring without observable winter injury. Plains bluestem recovered very slowly but stands of the other bluestems were essentially lost.

\section{Conclusions}

Caucasian bluestem was lower in IVD than Plains bluestem and experimental bluestem strains $B, L, L L$, and $T$, and PM-K-24 Eastern gamagrass. The CP content followed the same pattern but the differences were not significant. Although Plains and the experimental bluestems possessed higher IVD than Caucasian, they lacked winter hardiness. Both Caucasian bluestem and PM-K-24 Eastern gamagrass appeared equally winter hardy but the gamagrass was higher 
yielding and was higher in IVD than Caucasian bluestem. Certainly both these grasses would offer more production than tall fescue in the summer in southern Illinois but any quality advantage may be questionable. Imposing shorter cutting intervals could increase the CP and IVD levels and would be a necessary step to determine potential performance of these grasses for grazing.

\section{Literature Cited}

Barnes, R.F. 1969. Collaborative research with the two-stage in vitro rumen fermentation technique. Nat. Conf. on Forage Evaluation and Utilization. Nebraska Center for Continuing Education. Lincoln, Nebraska N1-N18.

Branson, F.A. 1953. Two new factors affecting resistance of grasses to grazing. J. Range Manage. 6: 165-171.

Bush, L.P., J.A. Boling, G. Allen, and R.C. Buckner. 1972. Inhibitory effects of perloline to rumen fermentation in vitro. Crop Sci. 12: 277-279.

Hanson, A.A. 1972. Grass varieties in the United States. USDA-ARS Agr. Handbk No.170, p. 115.

Harlan, J.R., H.R. Chheda, and W.L. Richardson. 1962. Range of hybridization with Bothriochloa intermedia ( $\mathrm{R}$. Br.) A. Camus. Crop Sci. 2: 480-483.
Kaiser, C.J., A.G. Matches, F.A. Martz, and G.D. Mott. 1974. Seas trend of in vitro dry matter digestibility and animal performance $f$ grazed tall fescue pastures. Twelfth Int. Grassl. Cong. Proc. Vol. III 1: 225-236.

Kessler, K. 1978. Better grasses ahead. The Furrow. Nov.-Dec. 1978: 16 Mott, G.D., C.J. Kaiser, R.C. Peterson, R. Peterson, Jr., and C.L. F kerd. 1971. Supplemental feeding of steers on Festuca arundinc Schreb. pastures fertilized at three levels of nitrogen. Agron. J. 751-754.

Roundtree, B.H., A.G. Matches, and F.A. Martz. 1974. Season too 1 for your grass pastures? Crops and Soils 26: 7-10.

Smith, A.E. 1977. Influence of temperature on tall fescue forage quality culm base carbohydrates. Agron. J. 69: 745-747.

Steinhardt, G.C., and D.P. Franzmeier. 1979. Chemical and mineralog properties of the fragipans of the Cincinnati Catena. Soil Sci. Soc. Ar Proc. 43: 1008-1013.

Schwendiman, J.L., and V.B. Hawk. 1973. Miscellaneous grasses. Forages, Third Edition. Eds. M.E. Heath, D.S. Metcalfe, and I Barnes. The Iowa State University Press. p. 242. 755 p.

Taliaferro, C.M., and J.R. Harlan. 1973. Registration of Plains bluest Crop Sci. 13: 580.

Vartha, E.W., A.G. Matches, and G.B. Thompson. 1977. Yield and que trends of tall fescue grazed with different subdivisions of pasture. Ag1 J. 69: 1027-1029. 